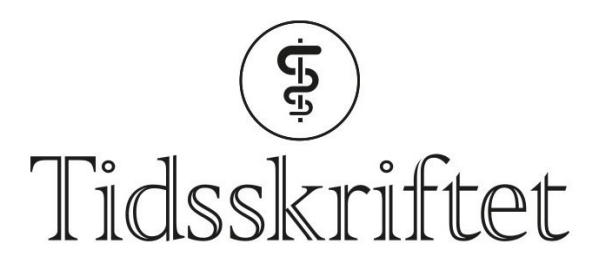

DEN NORSKE LEGEFORENING

\title{
Helse uansett størrelse
}

KRONIKK

\section{GRO BEATE SAMDAL}

E-post: gro.samdal@igs.uib.no

Gro Beate Samdal (f. 1958) er sykepleier, cand.san. og ph.d.-stipendiat ved Forskningsgruppe for allmennmedisin, Institutt for global helse og samfunnsmedisin, Universitetet i Bergen. Forfatter har fylt ut ICMJE-skjemaet og oppgir ingen interessekonflikter.

\section{EIVIND MELAND}

Eivind Meland (f. 1950) er fastlegevikar og professor emeritus ved Forskningsgruppe for allmennmedisin, Institutt for global helse og samfunnsmedisin, Universitetet i Bergen. Forfatter har fylt ut ICMJE-skjemaet og oppgir ingen interessekonflikter.

Slanking fører ikke til mindre sykelighet og lavere dødelighet. Slike forsøk på å oppnå god helse er som regel en håpløs strategi. Vi presenterer en alternativ folkehelsestrategi bygd på aksept, selvaksept og vennlighet.

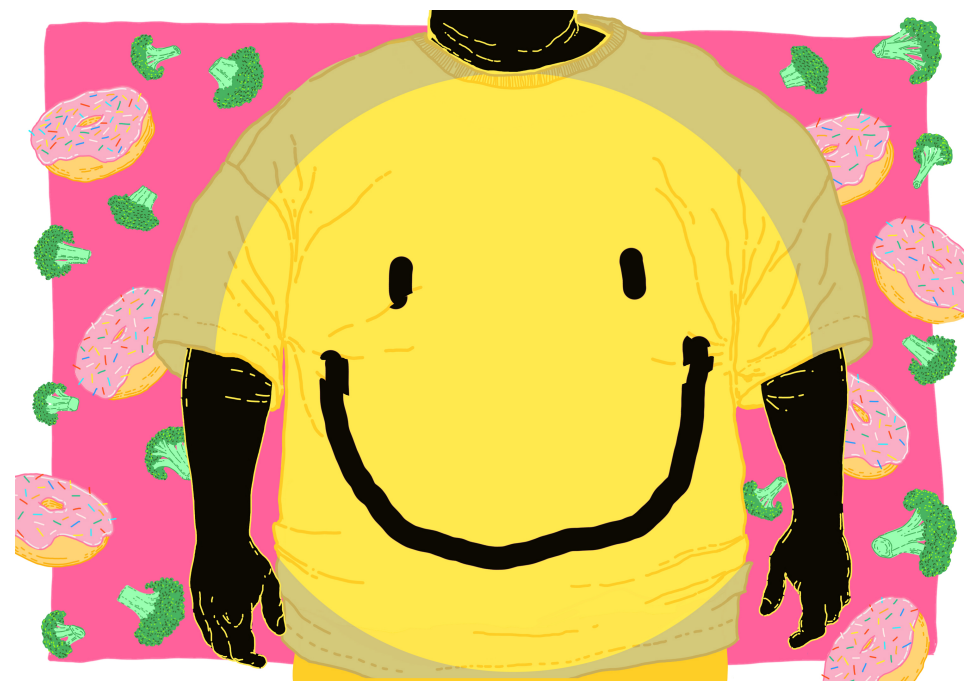

Illustrasjon: Sylvia Stølan

En uttalt sannhet er at overvekt fører til sykdom og økt dødelighet og at helsearbeidere derfor bør oppfordre overvektige til å slanke seg.

Men stemmer det at overvekt fører til økt sykelighet og tidligere død? Og hjelper det å slanke seg? Den kanskje mest kjente undersøkelsen der man har sett på sammenhengen mellom helse og vekt, er den randomiserte, kontrollerte Look AHEAD-studien (1). Der undersøkte man effekten av vekttap på risikoen for hjerte- og karsykdommer og tidlig død hos overvektige og fete mennesker med diabetes type 2.

Intervensjonen besto av veiledning, individuelt og i grupper, en gang ukentlig i seks 
måneder, med avtagende oppfølging i studieperioden. Man fremmet et kosthold med under 1 200-1 8oo kalorier per dag og mer enn 175 minutter med fysisk aktivitet per uke. Etter 11 år hadde slankegruppen 2,5\% lavere vekt enn dem som fikk vanlig diabetesbehandling. Det var signifikante forskjeller i midjemål, fysisk form og $\mathrm{HbA}_{\mathrm{tc}}$-nivå, men det var ingen forskjell mellom gruppene i sykelighet og dødelighet. Man konkluderte med at livsstilsendringene og vekttapet ikke ga mindre sykelighet og lavere dødelighet i en gruppe med stor risiko for hjerte- og karsykdom.

Vi har tidligere argumentert for at sammenhengen mellom overvekt og dårlig helse ikke er så entydig som helsemyndighetenes vil ha oss til å tro (2). Uansett hvilke metoder man bruker for å slanke seg, får man en vektreduksjon på kort sikt. Men på lang sikt kommer kiloene tilbake, og ofte er de flere enn før (3-5).

Slankekonkurranser er blitt populær TV-underholdning, ett eksempel er The biggest loser. Forskere har studert hva som skjer i kroppen til vinnerne av slike konkurranser. I en studie der man undersøkte dette, fant man at deltagerne seks år senere hadde lavere forbrenning og hadde gjenvunnet $70 \%$ av vekttapet (6).

Forskning på hva som skjer i kroppen under et vekttap, viser at forbrenningen reduseres og at produksjonen av hormoner knyttet til sult- og metthetsfølelse endres. Man blir mer opptatt av mat og får mindre lyst til å være aktiv. Disse mekanismene er automatiske og stimulerer til vektoppgang på sikt (7). Hvis ikke «vellykkede slankere» fra The biggest loser klarer å beholde vekten på sikt, hvordan kan da vanlige folk klare det?

Vi vil hevde at kampen mot overvekt og søken etter den «normale» vekten eller kroppen er til skade for folk i alle størrelser og fasonger. Mislykkede forsøk på slanking resulterer i overdreven oppmerksomhet omkring mat og vekt, stadige slankekurer, dårlig selvbilde og misnøye med kroppen - og mange kroner kastet bort på slankeprodukter. Ved å gjøre vekten til et individuelt ansvar påfører helsevesenet mennesker nederlag og skam når de ikke klarer å gå ned eller holde vekten på sikt.

Flere kunnskapsoppsummeringer viser hvordan fordommer mot overvektige og fete mennesker fører til diskriminering - i familien, i utdanning, i helsevesenet og i arbeidslivet. Diskriminering av store kropper kan sammenlignes med diskriminering ut fra sosial klasse, rase, kjønn eller seksuell legning $(8,9)$.

\section{Fra vekt til helse}

Flere og flere har satt spørsmålstegn ved om det er etisk forsvarlig å anbefale metoder med lav suksessrate og potensielle skadevirkninger. De mener at helsemyndighetene overdimensjoner risikoen ved overvekt og underkjenner at mange er sunne til tross for overvekt $(7,10,11)$.

Ett alternativ er å flytte oppmerksomheten fra vekt til helse. Health at every size (HAES) er en beskyttet merkevare for The Association for Size Diversity and Health, som oppsto blant borgerrettighetsorganisasjoner og helsepersonell som jobbet med spiseforstyrrelser i USA. Bevegelsen argumenterer for en slankefri (non-diet) tilnærming til velvære.

På norsk har vi kalt denne tilnærmingen «Helse uansett størrelse» (HUS). Den bygger på tre prinsipper. Disse er et fleksibelt forhold til mat, glede ved bevegelse og fysisk aktivitet og aksept og respekt for at mennesker har kropper i ulike størrelser og fasonger. Undervisning eller veiledning basert på disse prinsippene vektlegger at man skal nyte maten og lytte til kroppens signaler om sult, metthet og appetitt (ofte kalt oppmerksom eller intuitiv spising). Ingen matvarer er forbudt, men man får råd om å spise variert kost som gjør kroppen godt. Det vil for eksempel si mat som gir energi, som metter og gir velvære og som fremmer tarmtømmingen.

Fysisk aktivitet anbefales for å forebygge en rekke kroniske sykdommer eller fremme helse og må tilpasses den enkeltes motivasjon, styrke og helsetilstand. Vekttap er ikke et mål i kost- eller aktivitetsveiledningen, men kan komme som et naturlig resultat av endrede 
vaner over tid.

Kroppsaksept innebærer at man ikke vurderer folks helse ut fra kroppsmasseindeks eller vekt og ikke bruker ladede betegnelser som normal vekt, overvekt eller sykelig overvekt. Alle kropper fortjener respekt, og helsepersonellets holdninger skal avspeile dette. Det gjelder også i innredning av lokalene. Toaletter, stoler og undersøkelsesbenker må passe for kropper i alle størrelser og fasonger.

HUS-bevegelsen er blitt kritisert for å benekte sammenhengen mellom vekt og helse (12). Dette er imidlertid ikke riktig. Tilhengerne påpeker bare at sammenhengen er komplisert, og at det er mer hensiktsmessig å rette oppmerksomheten mot helse heller enn vekt. En annen vanlig innvending er at intuitiv spising fremmer et usunt kosthold eller overspising, ved å formidle at det er greit å spise hva som helst. HUS-tilhengerne på sin side hevder at overspising er resultat av at noen matvarer er «forbudt» $i$ et strengt kostholdregime. Man får en sprekk og mister selvkontrollen (12). Når all mat er lov, om enn ikke alltid, kan man spise sin mat og nyte den uten dårlig samvittighet. Dermed blir det mindre sannsynlig med overspising.

Det er etter hvert kommet studier av vektnøytrale intervensjoner bygd på prinsippene fra HUS-bevegelsen. Kunnskapsoppsummeringer av slike intervensjoner gir grunn til optimisme. Det er positive funn på ulike effektmål, blant annet stabilisering av vekt, bedre psykisk helse, muligens bedre helseindikatorer (blodtrykk, kolesterolnivå), sunnere kostog spisevaner, bedring i spiseforstyrrelser, selvfølelse og depresjon. Det er færre som dropper ut, og endringene varer ved i opptil to år (13-15). Ingen av disse kunnskapsoppsummeringene viser negative helseeffekter eller vektoppgang.

\section{En ny folkehelsestrategi}

Vi mener at helsemyndighetenes råd til personer med overvekt og fedme om å gå ned i vekt for å få bedre helse, ikke virker og er forfeilet. Når ledende forskere maner til økt kaloridisiplin i matfatet, retter de baker for smed (16). Det er slankerådene som er feil. De har bidratt til at vi er fetere enn vi ellers ville ha vært.

Når det gjelder hva som påvirker folkehelsen på samfunnsnivå, er det stort sett enighet om fem elementer: genetiske faktorer, levevaner, helsevesenet og fysiske og sosiale forhold (17). Man vet ikke hvor stor del folks levevaner utgjør, men Centers for Disease Control and Prevention har gjort et grovt anslag om at det er under $20 \%$ (17). Dette innebærer at vi trenger en folkehelsestrategi som virker på flere områder i samfunnet. Tiltak på politisk nivå og på samfunnsnivå virker også mer sosialt utjevnende enn tiltak på individnivå (11).

Vi kan lære mye av hvordan det ble jobbet med å forebygge lungekreft $(11,18)$. Kampen mot tobakk er et eksempel på en folkehelsestrategi med flere virkemidler, blant annet lovgivning, forbud mot reklame, krav til markedsføring, avgiftspolitikk, medisinsk behandling og støtte til dem som trenger hjelp til å slutte.

På individnivå skal alle med lungekreft eller overvekt få god og respektfull medisinsk behandling, uansett årsak til sykdommen. «Nedstrøms» individrettede tiltak er imidlertid ikke tilstrekkelig som folkehelsestrategi. Mangelfull effekt av intervensjoner på overvekt er et sterkt argument for å satse på en alternativ folkehelsestrategi (11).

Samtidig må helsemyndighetene slutte å omtale det å endre levevaner som enkelt, som om det bare er å spise mindre og være mer fysisk aktiv (19). Menneskene er ikke dumme, de er kunnskapsrike aktører med løsninger på sine egne problemer. Her ligger også motivasjonen til endring og vedlikehold av endring på sikt.

Som en konsekvens av at folk forstår at det å slanke seg er et håpløst prosjekt for de aller fleste, er det i USA nå færre enn tidligere som forsøker å gå på diett (20). Slankeindustrien og ukeblader som registrerer nedgangen, har skiftet språk i markedsføringen. En artikkel i New York Times Magazine beskriver hvordan slankebedriften Weight Watchers endret budskapet til sine kunder fra slanking til livsstil som følge av dårlige salgstall (21). Men er det 
ikke samme individualiserte budskap om selvkontroll i ny innpakning?

Menneskers atferd og levevaner er ikke et resultat av tilfeldige valg, det er rasjonelle og automatiserte handlinger, vaner og sosiale mønstre innvevd i en sosial struktur og kultur (22). Å endre levevaner er komplisert, og å veilede om endring av levevaner krever mer enn sunn fornuft. Helsepersonell og helsemyndigheter må ha psykologisk kunnskap, etisk beredskap og kunne forstå menneskers atferd som sosiale praksiser. Den erkjennelsen som «Helse uansett størrelse» er et uttrykk for, representerer en alternativ etisk horisont til et individualisert, diagnostiserende og selvkontrollerende paradigme i medisin, sosialmedisin og helsefag.

Vi ønsker velkommen et paradigme bygd på aksept, selvaksept, vennlighet og tillit til kroppen og naturen, som vi alle er del av (23).

\section{LITTERATUR:}

1. Davis NJ, Goswami G. Modest weight loss does not decrease cardiovascular morbidity and mortality in adults with type 2 diabetes. Evid Based Med 2014; 19: 64. [PubMed][CrossRef]

2. Samdal GB, Meland E. Er det overvekt eller vektfokus som er helseskadelig? Tidsskr Nor Legeforen 2014; 134: 2247 - 8. [PubMed][CrossRef]

3. Look AHEAD Research Group. Eight-year weight losses with an intensive lifestyle intervention: the look AHEAD study. Obesity (Silver Spring) 2014; 22: 5 - 13. [PubMed][CrossRef]

4. Wing RR, Hamman RF, Bray GA et al. Achieving weight and activity goals among diabetes prevention program lifestyle participants. Obes Res 2004; 12: 1426 - 34. [PubMed][CrossRef]

5. Wing RR, Phelan S. Long-term weight loss maintenance. Am J Clin Nutr 2005; 82 (suppl): 222S - 5S. [PubMed]

6. Fothergill E, Guo J, Howard L et al. Persistent metabolic adaptation 6 years after "The Biggest Loser" competition. Obesity (Silver Spring) 2016; 24: 1612 - 9. [PubMed][CrossRef]

7. Tylka TL, Annunziato RA, Burgard D et al. The weight-inclusive versus weight-normative approach to health: evaluating the evidence for prioritizing well-being over weight loss. J Obes 2014; 2014: 983495. [PubMed][CrossRef]

8. Puhl RM, Heuer CA. The stigma of obesity: a review and update. Obesity (Silver Spring) 2009; 17: 941 64. [PubMed][CrossRef]

9. Puhl RM, Andreyeva T, Brownell KD. Perceptions of weight discrimination: prevalence and comparison to race and gender discrimination in America. Int J Obes 2008; 32: 992 - 1000. [PubMed][CrossRef]

10. Bombak AE. The contribution of applied social sciences to obesity stigma-related public health approaches. J Obes 2014; 2014: 267286. [PubMed][CrossRef]

11. Brownell KD. The humbling experience of treating obesity: Should we persist or desist? Behav Res Ther 2010; 48: 717 - 9. [PubMed][CrossRef]

12. Bacon L, Aphramor L. Weight science: evaluating the evidence for a paradigm shift. Nutr J 2011; $10: 9$. [PubMed][CrossRef]

13. Van Dyke N, Drinkwater EJ. Relationships between intuitive eating and health indicators: literature review. Public Health Nutr 2014; 17: 1757 - 66. [PubMed][CrossRef]

14. Clifford D, Ozier A, Bundros J et al. Impact of non-diet approaches on attitudes, behaviors, and health outcomes: a systematic review. J Nutr Educ Behav 2015; 47: 143 - 55.e1. [PubMed][CrossRef] 15. Schaefer JT, Magnuson AB. A review of interventions that promote eating by internal cues. J Acad Nutr Diet 2014; 114: 734 - 6o. [PubMed][CrossRef]

16. Leblanc V, Provencher V, Bégin C et al. Impact of a Health-At-Every-Size intervention on changes in dietary intakes and eating patterns in premenopausal overweight women: results of a randomized trial. Clin Nutr 2012;31: 481 - 8. [PubMed][CrossRef] 
17. Tarlov AR. Public policy frameworks for improving population health. Ann N Y Acad Sci 1999; 896: 281 - 93. [PubMed][CrossRef]

18. Sniehotta FF, Araújo-Soares V, Brown J et al. Complex systems and individual-level approaches to population health: a false dichotomy? Lancet Public Health 2017; 2: e396 - 7. [PubMed][CrossRef]

19. Forebygging, utredning og behandling av overvekt og fedme hos voksne. Oslo: Helsedirektoratet, 2011.

http://www.helsedirektoratet.no/publikasjoner/nasjonal-faglig-retningslinje-for-forebygging-utredni ng-og-behandling-av-overvekt-og-fedme-hos-voksne/Sider/default.aspx (30.11.2017).

20. Snook KR, Hansen AR, Duke CH et al. Change in percentages of adults with overweight or obesity trying to lose weight, 1988-2014. JAMA 2017; 317: 971 -3. [PubMed][CrossRef]

21. Brodesser-Akner T. Losing It in the Anti-Diet Age. New York Times Magazine 2.8.2017.

22. Kelly MP, Barker M. Why is changing health-related behaviour so difficult? Public Health 2016; 136: 109-16. [PubMed][CrossRef]

23. Hayes S, Strosahl K, Wilson K. Acceptance and Comittment therapy. The Process and Practice of Mindful Change. New York: The Guilford Press, 2012.

Publisert: 19. februar 2018. Tidsskr Nor Legeforen. DOI: 10.4045/tidsskr.17.0863

Mottatt 9.10.2017, første revisjon innsendt 9.11.2017, godkjent 30.11.2017.

(C) Tidsskrift for Den norske legeforening 2020. Lastet ned fra tidsskriftet.no 